\title{
On Parting, Separation and Longing in the Chinese Poetic Tradition
}

\author{
MAJA LAVRAČ
}

\begin{abstract}
The article introduces two conventional themes, namely, parting and separation imbued with longing in the Chinese poetic tradition of the Tang period (618-907). It focuses on the interpretation of selected Tang poems written by the famous poets Wang Wei, Li Bai, Du Fu, Du Mu, Bai Juyi and Li Shangyin. Parting from an old friend, who was usually also a fellow official at the court in the then capital Chang'an (now Xi'an), was a common occasion for versification. More than half of the poems presented and discussed in the article illustrate this poetic genre, since the cult of friendship played an important role in everyday life in traditional China.

In addition to parting poems, the article deals also with the second conventional theme: separation and longing between husband and wife. This topic, too, was often transformed into poems expressing the helplessness and despair of one of the partners due to a long-time absence of the other. Despite all the suffering, there is always hope of a reunion eventually.

Both groups of poems are permeated with feelings of sadness and melancholy embodied in a simple, yet elegant language. Linguistic simplicity is a significant feature of the traditional Chinese poetry which culminated in the Hight Tang, i.e. in the eighth century.
\end{abstract}

Keywords: Chinese poetic tradition, friendship, parting, separation, longing

\section{Introduction}

Parting poems and poems on separation and longing represent an important part of the Chinese poetic tradition of the Tang period (618-907). Those three hundred years are regarded as the golden age of Chinese poetry - when this poetry reached its zenith. At that time, presumably more than two thousand poets wrote the almost fifty thousand poems collected in the famous anthology Complete Tang Poetry. Among them were such great masters as Wang Wei, Li Bai, Du Fu, Du Mu, Bai Juyi and Li Shangyin, just to mention some of them.

The poems of parting occupied a prominent position in Chinese poetry, since parting from an old friend was a frequent occasion for composing poetry. In traditional China, the poets used to cultivate "one of the oldest and 
LAVRAČ

foremost arts in China - friendship. "Friendship occupied the entire stage of both everyday feelings and deepest passion" (Barnstone 1989: 40). Its moral, aesthetic and intellectual values had great impact on the culture of that time. Therefore, friendship in all its dimensions is prevalent in parting poems. Seeing off a dear friend, usually a fellow official who was sent by the emperor to take on a new job or who had been degraded and exiled far away from the capital, often to a province in the border area of the empire, is one of the most common topics, and a typical feature of the life of a court official. Setting out for a distant, unknown place, and the loss (sometimes a temporary, yet many a time a permanent one) of a close friend deeply affected the poet. Since the act of parting was imbued with a sense of melancholy, sadness and pain, some of the most beautiful Chinese poems can be found in this poetic genre.

Besides the theme of bidding farewell to a friend or a lover, many Tang poems sing about love and its pangs, such as the pain of separation between husband and wife and never-ending longing for the beloved. In contrast to the poetry of other cultures, traditional Chinese poems on separation and longing do not speak about this subject matter directly; they do so indirectly, using images and associations suggesting a variety of feelings that the couple's particular situation evokes. Though they deal with this topic, neither separation nor longing are mentioned or described as such.

\section{The Theme of Parting}

李白: 送友人 ${ }^{1}$

青山横北郭, 白水绕东城。 此地一为别, 孤蓬万里征。 浮云游子意, 落日故人情。 挥手自兹去, 萧萧班马鸣。

\section{Li Bai}

\section{SEEING OFF A FRIEND}

Green hills stretch across the north outskirts of the city white water winds around the east wall

Here we bid each other goodbye and you

like a lone tumbleweed

\footnotetext{
1 For the poems in Chinese please see Internet References.
} 
On Parting, Separation and Longing in the Chinese Poetic Tradition

will go far away

Drifting clouds

life of a wanderer

The setting sun

feelings of old friends

Waving our hands we take leave

our horses neighing xiaoxiao

(Trans. by M. Lavrač)

The poem, imbued with stock images, sings about friendship and the sadness that parting from a friend usually causes. It actually reveals how significant friendship is for Li Bai (701-762). He places a great value on it since he knows that after his friend is gone he will most likely never see him again. During those years transport in China was very slow. Besides, travelling alone was unsafe and risky.

At the beginning, the poet paints the picture around him and his friend. In this manner he provides the background with the mountains and the river his friend is soon going to leave behind. Employing the image of water, he not only depicts the landscape, but primarily points out its metaphorical meaning that symbolizes never-ending movement. In this way, he alludes to their eternal friendship.

Furthermore, the reader is presented with the image of lonely tumbleweed that symbolizes a traveller - his friend who is parting from him and setting off on a long journey. The poet is aware that he might not see him again.

In the second half of the poem, we come across very powerful and emotionladen conventional images which embody its quintessence. Even though the poet does not express his feelings directly, his sorrow and melancholy can be easily felt. A thoughtful combination of images hints at this kind of sentiments. Li Bai does not say anything about how he feels; nevertheless, one gets a picture that is pervaded with grief and sadness. The "drifting clouds" is a forceful nature image symbolizing freedom. Therefore, it can be compared to the wanderer's life, expressing his ideal. The image of "the setting sun" also powerfully alludes to the old friend's feelings. That the two of them do not want to part is reflected in the sun's reluctantly sinking behind the hills. The usage of the word "old" emphasizes here the fact they are very close friends, i.e. their everlasting friendship. Though both images - "the drifting clouds" and "the setting sun" - are the objects of the poet's contemplation of nature on the first, literal level, on a metaphorical level, they symbolize the relationship between the poet and his friend as well as the poet's emotions, thus carrying a more significant message. 
LAVRAČ

Towards the end of the poem, when the friends actually part, we again cannot find any direct emotional outburst. Rather, the poet offers us a simple description of their departure: they merely wave to each other while their horses are neighing. We are left with a premonition that the two of them will probably never meet again (Lavrač 2001: 152-153).

李白: 送孟浩然之广陵

故人西辞黄鹤楼, 烟花三月下扬州。

孤帆远影碧空尽, 唯见长江天际流。

Li Bai

SEEING MENG HAORAN OFF TO GUANGLING ${ }^{2}$

My old friend bid farewell to the West at the Yellow Crane Tower.

He is going downstream to Yangzhou

on this April day of misty flowers.

The distant image of his lonely sail

vanishes under the emerald sky.

All I see now is the Long River

flowing to the end of the horizon.

(Trans. by E. C. Chang)

One of Li Bai's most popular farewell poems, he devoted it to his dear friend the poet Meng Haoran (689-740). It is rich in sound and fluid in structure, its nature imagery evoking the fascinating landscape amid which the parting takes place. The beautiful scenery serves in fact as a cover-up for the poet's sadness and pain at his friend's departure.

The Yellow Crane Tower offers a beautiful view of two rivers, of the grandiose Long River (Yangtze) and the Han River that flows into the former. Meng Haoran had travelled from his mountain refuge down the Han River, and was going to continue his journey down the Long River to the city of Yangzhou. Li Bai, very likely, had come from far away to meet his old friend and wish him a safe journey. Here, the month of April refers to the third month in the traditional Chinese lunar calendar.

\footnotetext{
2 Another name for Yangzhou.
} 
The poem itself is like a river. It flows together with the Long River from the Yellow Crane Tower, to the departure of the friend's sailing boat and its dwindling away into the vast sky, and finally, to the river streaming eastwards and disappearing over the horizon (Whincup 1987: 55-56).

\author{
王维: 渭城曲 \\ 渭城朝雨淏轻尘, 客舍青青柳色新。 \\ 劝君更尽一杯酒, 西出阳关无故人。 \\ Wang Wei \\ SONG OF WEI CITY \\ In Wei city morning rain \\ has drenched the light dust; \\ Green, green the young leaves of the willows \\ beside the inn. \\ Let me persuade you - empty one more wine-cup: \\ There are no friends where you are going \\ west of Yang pass!
}

(Trans. by I. Herdan)

Wang Wei (701-761) is saying goodbye to his dear friend who is most likely leaving to take up a new post in central Asia, i.e. in the Gobi desert (in those times this was the frontier region of Anxi, modern Xinjiang, and the Yang Pass, which was in Dunhuang of Gansu province). He tries to persuade him to drink a last cup of wine and enjoy the present moment, which he emphasizes by his fatal vision of the future. The latter is merely hinted at by the repetition of the symbolic act of drinking wine in the company of his old friend, which assumes a new meaning since this time they are probably toasting each other for the last time.

Wang Wei compares the joy of the present moment with what awaits his friend in the future. He is aware that the present cannot go on forever and that their separation is inevitable. In the first half of the poem, he gives us detailed aspects of the town his friend, who is heading for the border region, is leaving and which he is most probably going to miss. Since this area west of the Yang Pass was the Gobi desert, and as such evokes immense solitude, the green willows and refreshing morning rain will for him be as rare and 
LAVRAČ

valuable as drinking wine in the company of his dear friend. Just as the earth without water and life turns into a desert, so there will be no one to welcome him with a cup of wine once he crosses the Yang Pass (Barnstone 1989: 37). For the poet's friend, who will most likely not return before the next spring if not many years later, the described scene carries a special meaning - it will, in fact, take quite some time before he will be able to enjoy the domestic environment again. The poet, therefore, instantly suspends the present to avoid the sense of sadness and solitude predicted by the future. Instead of lamenting over his friend's departure, he generalizes his individual experience. The present joy and consolation will come to an end as soon as the parting moment is up, the moment embodied by the poem itself. Thus its closure hints at Wang Wei's famous and characteristic silence beyond the words (Wagner 1975: 32).

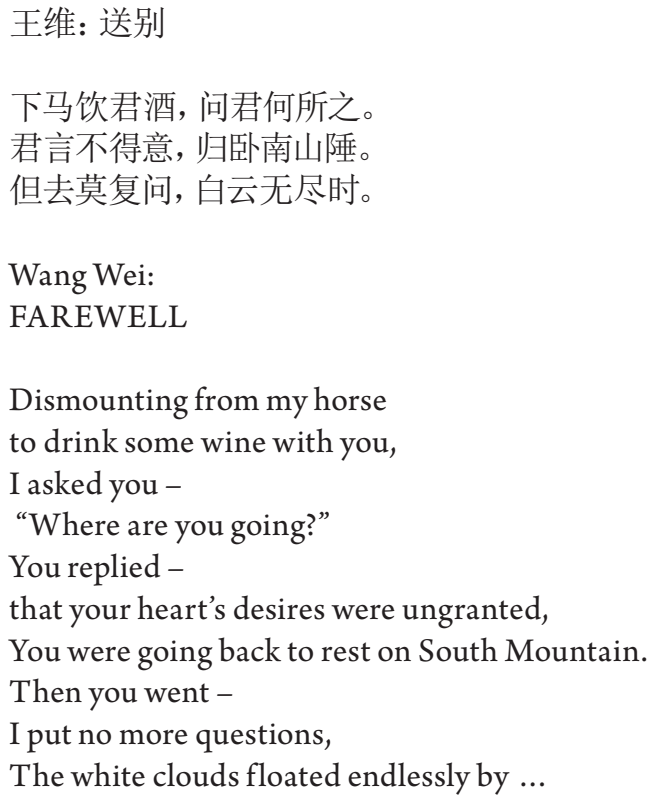

(Trans. by I. Herdan)

The poem addresses "the few central issues: failure to attain one's ambition, returning to the mountains, and leaving mundane affairs without asking unanswerable questions" (Wagner 1975: 189). It can be interpreted either as a real situation put into words by the poet in order to talk about fundamental life decisions, or as an imaginary dialogue between the poet and his unsuccessful 
friend as they discuss the eternal dilemma of their lives - that is, being torn between their official duties at the court in the capital and their retreat to the countryside, to the mountains, between the dusty and noisy life of the city and the tranquil solitude of nature. In his friend's reply we can sense his disappointment at the falsehood of official life and his failure in politics, and hence his wish to withdraw to the solitude of the South Mountain, to return to nature.

In the last line of the poem, we come across one of Wang Wei's favourite nature images, white clouds, which carry a wealth of associations and therefore offer various interpretations. From the poet's biography we know that, like his friend, he too found his retreat in Lantian at the foot of the South Mountain. This can be interpreted as indicating that both the white clouds and the mountain solitude hint at his wish to ultimately withdraw from worldly affairs. The two images can symbolize the transcendental nature of life in seclusion, since the realm of white clouds is endless, limitless and beyond all sensual and rational forms of comprehension of the world. Perhaps there is something consoling in them as they, with their whiteness, primeval purity and tranquillity, evoke timelessness and limitlessness "in contrast to the world of limits and time which the traveller is leaving" (Yu 1980: 130). Since their actual meaning is beyond the reach of the human mind, no statement about them can be made. The same holds true for the Buddhist sunyata or emptiness, the transcendence of existence, all of which are its specific features. Wang Wei, as a Buddhist, is constantly aware of the unsuitability and deficiency of words to express the inconceivable and inexpressible absolute reality, i.e. the emptiness of the universe. Hence the poem's utmost linguistic simplicity, taciturnity, conciseness and open poetic closure. Literally translated, the last line reads "The white clouds are endless," which alludes to timelessness, a sphere beyond time, spiritual freedom and Buddhist enlightenment.

\section{王维: 送别}

山中相送罢, 日暮掩柴扉。 春草年年绿, 王孙归不归。 
LAVRAČ

\author{
Wang Wei \\ FAREWELL \\ Among the mountains \\ we bade each other farewell; \\ The sun sank \\ as I closed the wicker gate. \\ Grass will be green again \\ another spring \\ But will my prince of friends ${ }^{3}$ \\ return or no?
}

(Trans. by I. Herdan)

The poem can be regarded as an extended allusion to the lines in the renowned anthology Songs of Chu: "You travel off, aye, and do not return; the spring grass grows, aye, luxuriant" (Johnson 2000: 20). As a Buddhist devotee, Wang Wei often sought withdrawal in nature. He dedicated these lines to his close friend and fellow official who is bidding farewell to him in the mountains and going back to the court in the capital. So, the poet, who is returning to the seclusion of his rustic home after having parted from his friend, is asking himself whether or not his friend will return to the simple, natural life in the solitude of the mountains. "The question of 'returning' is a recurrent thematic ambiguity in Wang Wei's poetry" (Wagner 1975: 171). Though the poet is aware that his friend will be busy performing his official duties, he still hopes and anticipates that sooner or later he will long for the embrace of nature.

At the beginning of the poem, Wang Wei, using the phrase "among the mountains", is undoubtedly alluding to his withdrawal into intimate seclusion far away from people and the hustle of city life. The mountains he is talking about are those around his estate at Lantian, south of the capital, where he retired in his later years. This isolation is further emphasized by his act of closing the gate behind himself after his friend left. In this way, his isolation is double. He offers us a description of two final human actions. A hint of finality can be found in the line "we bade each other farewell", which suggests the short-lived nature of human company or human relationships as well as the transience of one's experience, so the act of closing the gate, temporally defined by the setting sun, means the end of the day, and in this way also "lends a note of finality and resignation to the act of saying good-bye" (Feinerman 1979: 40)

3 "... prince of friends" or "wangsun" in Chinese means offspring of the nobility; here it refers to his friend and is usually associated with spring grass. 
From a parting scene in nature, the poet created an excellent poetic occasion to express man's fragility, insignificance and transitoriness.

When Wang Wei writes that grass will be green another spring, he introduces the main idea of the poem - he emphasizes the eternal revival of nature within the annual cycle, and by this evocation of eternal change he symbolizes his hope of his friend's return. Though the grass withers each autumn, each spring it becomes green again. Yet he is aware that "there is not the same assurance for a person as there is for Nature" (Feinerman 1979: 41). Besides, the poet identifies himself with his friend, since in his later life he himself was torn between the court and the countryside. The question of return is indeed quite often a matter of ambiguity in Wang Wei's poetry. Therefore, the poem's closure is a poignant mixture of sadness and pain at parting and, simultaneously, of consolation. As such, it can be understood as a meditation on man's life, on the reality of human existence, as an embodiment of the transience of a moment, of that question without an ultimate answer.

\section{白居易: 草}

离离原上草, 一岁一枯荣。

野火烧不尽, 春风吹又生。

远芳侵古道, 晴翠接荒城。

又送王孙去, 萋萃满别情。

Bai Juyi
GRASS

How the wild grasses spread over the plain!

Year after year they wither to sprout afresh:

even heath fires cannot burn them up -

When the spring winds blow they rise again.

Their scent creeps on to the ancient road;

Their immaculate green clasps the ruined wall.

Now as I bid my noble friend farewell

I find the endless grasses

heavy with regret.

(Trans. by I. Herdan)

Bai Juyi (772-846) wrote this poem at the age of 16. In traditional Chinese poetry the image of grasses was used in connection with emotions on parting. 
LAVRAČ

The first half of the poem portrays the location where the poet says goodbye to his friend. It sings of the grasses and their great power of resistance - even the wildfire cannot destroy them. Therefore, the next spring they will thrive again. Every year grass follows its natural cycle of death and re-birth. The poet here emphasizes its tenacity, emerging from the earth again and again no matter how many times it is extinguished, and he "contrasts Nature's powers of renewal with human vulnerability in the face of separation” (Barnes 2007: 273). At an additional, deeper level this image of grass may also evoke the indestructibility of a close friendship put on a trial by parting.

The next two lines describe the grasses in all their luxuriant green that overgrows the ruined wall and in their intoxicating fragrance that pervades the ancient road. The focus of the poem is now extended into the distance, pointing out the immense vitality of the grass, and thereby suggesting the moral qualities of the lasting friendship.

Bai Juyi concludes the poem with the act of parting from his beloved friend, an idea ingeniously expressed by the personification of the grass. The image of grass permeates the poem from beginning to end, symbolizing both their close friendship which, like persistent grass, will never die, and the parting pain in their hearts.

\section{杜牧: 赠别}

多情却似总无情, 唯觉尊前笑不成。 蜡烛有心还惜别, 替人垂泪到天明。

$\mathrm{Du} \mathrm{Mu}$

\section{GIVEN IN FAREWELL}

Deeply in love, but tonight we seem to be passionless; I just feel, before our last cup of wine a smile will not come.

The wax candle has sympathy weeps at our separation: Its tears for us keep rolling down till day breaks. 
On Parting, Separation and Longing in the Chinese Poetic Tradition

The poem is both a love and a parting poem revealing Du Mu's (803-852) romantic, sentimental side. The poet is very likely bidding farewell to his sweetheart. He is not willing to leave her. Though they are deeply in love, their love does not seem like love at all. Even the wine cannot bring a smile to their lips. The pangs of parting seem almost unbearable. The poet does not say anything about their sadness or their tears, but employs the image of the burning candle instead. The personified candle sheds tears for them until dawn. In this way, $\mathrm{Du} \mathrm{Mu}$ symbolically hints at their unwillingness to part, their helplessness and despair.

\section{The Theme of Separation and Longing}

李白: 春思

燕草如碧丝, 秦桑低绿枝。
当君怀归日, 是妾断肠时。
春风不相识, 何事入罗帏。

Li Bai

SPRING LONGING

When the grasses of Yan are like green silk threads

the mulberries of $Q$ in are heavy with verdant twigs

The days of your longing to return

are the days when my heart is breaking

The spring breeze

you stranger

How dare you

part the silk curtains round my bed

(Trans. by M. Lavrač)

The poem is a portrait of a common separation between husband and wife, the theme of which is indicated already in the title. Spring is the season of love, the time when hopes revive in one's heart. And absence of one of the partners, be it short or long, can bring about grief and despair in the one left behind.

The beginning of the poem is devoted to the coming of spring, to the rebirth of nature. The grass is compared to green silk threads, meaning that it is green and soft like silk, conveying its visual as well as its perceptible quality. We feel as if we can touch and caress it. Yet we cannot, since the grass is not 
just grass anywhere but it is the grass of Yan, which is another name for the far north-east region of China during the Tang period (now the area around Peking), where soldiers were stationed guarding the border (Whincup 1987: 96).

If we return to the silk threads, we can connect this image with silkworms and cocoons, which is implied in the second line. Mulberries, full of green buds so that they weigh down their twigs, denote sericulture, which can be associated with a woman's life and her work. A mulberry grove was not only a place where she would pick mulberry leaves to feed hungry silkworms, but also a place where lovers would meet, thus evoking erotic, sexual associations. Besides that, a woman would weave cloth to make clothes for her soldier husband or her lover fighting far away from home, the silk thread being here a symbol of longing love.

And again, the mulberries of the second line are not just mulberries anywhere, but the mulberries of Qin, a name indicating the area around Chang'an (now Xi'an), the then capital of Tang China, i.e. the west, the western edge of the North China Plain (Whincup 1987: 96). If we carefully examine both place names, we can gain a clear insight into the situation which might be the following: the wife at home in the west is longing for her soldier husband, who is fighting far away from home on the north-east frontier. Actually, this is a common female image in traditional Chinese poetry (ibid.). The vast distance engenders in her feelings of loneliness and solitude, sadness and despair, which is manifested in the subsequent lines.

The absent husband evokes the wife's eternal longing, and she faces the agony of uncertainty caused by their separation. She is waiting for him, deeply frustrated. Thinking of him, she knows that he too is yearning to return home, and this depresses her. Her heart is breaking, and she feels like she is going to die if he does not come back soon. Being alone for a long time is too much for her to take since she probably feels like a prisoner in her own bedchamber, waiting and longing night and day. Her life seems meaningless without the man she loves. But what can she do? Foreseeably, not much beyond staying at home patiently counting the days until his return. For her, separation is indeed a very painful experience, something too difficult to endure.

As we are approaching the end of the poem, we come across two interesting puns, namely spring breeze and silk. The image of spring breeze is a conventional symbol of love, lust and other sexual feelings, indicating that the married couple or lovers should together enjoy the arrival of spring. Yet in our poem, the wife is lying alone in her bed. And when the breeze parts the silk curtains round her bed, her first thought is that it might be her husband who has finally returned home and is going to lie down beside her. Silk, as 
On Parting, Separation and Longing in the Chinese Poetic Tradition

mentioned, also carries a hidden erotic significance, and thus her bed with silk curtains suggests sensuality, a desire to make love. When the heartsick wife realizes that it is only the spring breeze, not her husband, that comes in through her bed curtains, she is very disappointed, and calls it a stranger, her feelings of loneliness seem to increase even more.

\section{杜甫: 月夜}

今夜鄜州月, 闺中只独看。 遥怜小儿女, 未解忆长安。 香雾云譬湿, 清辉玉臂寒。 何时倚虚幌, 双照泪痕干。

$\mathrm{Du} \mathrm{Fu}$ MOONLIT NIGHT

There will be moon tonight over Fu-chou.

In the women's rooms she is gazing at it alone.

From afar, I pity my little children: They do not know yet about Chang'-an. In the sweet mists her cloud-like hair is damp; In the clear shining her jade-white arms are cold. When shall we two lean beside the filmy curtain With moonlight on us both and the tear-stains dry?

The poem is an autobiographical account representing Du Fu's (712-770) personal experience, which for him is rather painful, making him suffer a lot. He wrote it in 756, when he was held in Chang'an by An Lushan's rebel army, ${ }^{4}$ while his family was at Fuzhou, 140 miles north of the capital. It is

\footnotetext{
4 An Lushan was a general in northeast China who rebelled against the Tang dynasty.
} 
LAVRAČ

an honest, unadorned declaration of his feelings of solitude, loneliness and longing caused by a violent separation from his wife and children. Traditional Chinese commentators regard it as the first Chinese poem in which the poet openly expresses his love for his wife. He does it in a very romantic way since the images he employs to conjure her were conventionally used for portraying court ladies.

The poem opens with a scene in which $\mathrm{Du} F u$ imagines his wife feeling lonely in their home at Fuzhou at night while watching the moon from her bedroom. Probably, she is standing by the window and, in the tranquillity of the night, thinking of him. The image of the moon and the place name Fuzhou allude to distance and separation. The moon is a symbol of spiritual connection between separated people (either between husband and wife or between lovers, friends or relatives) and longing for someone far away from home. It links them together in time and space. While watching the moon, the wife most likely becomes even more aware of her absent husband. Thus, her feelings ofloneliness increase. Mentioning Fuzhou, their home in the north, far away from Chang'an, where the poet was imprisoned, and the use of the word "alone" further intensify this kind of mood.

In the succeeding lines, Du Fu talks about his children who are too young to know where Chang'an is, i.e. where their father is. He feels pity for them since they are unable to understand why he is there. "The children, growing up in wartime, don't know what peace is" (Cheng 1982: 150). Very likely, he cannot bear to think of them. Having been separated from them for a long time makes him suffer great pain.

Further, the reader is confronted with a beautiful, romantic portrayal of the poet's wife embodied by a combination of images. Her damp hair is compared with clouds, the latter being associated with mists. But another interpretation is possible, namely that her hairstyle resembles clouds, and that her hair is damp due to a few drops of perfume.

In describing her arms, Du Fu compares them with jade, and thus lets us know that they are gentle, elegant and soft like jade. This precious stone is also a symbol of female purity and spiritual beauty. If we further analyse it, we can recall that it is cold to the touch. There is also a connection between jade and the moon since both normally radiate pure, clear, brilliant light. And finally, as we return to the description of her arms, the following question can be raised: Why are they cold? The answer is simple: Because she is lonely and longs for her dear husband far away from home.

The poem concludes with the poet wondering when the two of them together might lean beside the curtain and have the moonlight dry up their tear-stains. The final lines may indicate that he himself is probably standing 
by the window watching the moon, thinking of his wife and imagining himself gently stroking her hair and fondling her hands. He too feels lonely and longs to return to his family. Since strong sentiments often seem to be associated with tears, this can also mean that they both are crying, the separation simply being too painful. However, in spite of all this, Du Fu never stops hoping that one day he will return to his wife and children, to be reunited with his family. He believes that a time will come when the moonlight will finally dry up their tears of grief, and heal their pangs of pain.

\title{
李商隐: 夜雨寄北 \\ 君问归期未有期, 巴山夜雨涨秋池。 何当共剪西窗烛, 却话巴山夜雨时。
}

\section{Li Shangyin \\ FOR SOMEONE IN THE NORTH ON A RAINY NIGHT}

\author{
You ask me, when I shall return - \\ there's no date set. \\ Here at Pa-shan the evening rain \\ has brimmed the autumn pools. \\ When shall we trim our lamp-wicks \\ by the west window \\ While I tell you how the evening rain \\ came down at Pa-shan?
}

(Trans. by I. Herdan)

The poem was written by the late-Tang poet Li Shangyin (813-858) during his stay in Sichuan in the west, and was supposedly addressed to his wife in the north. Far from home, separated from his love and alone in the mountain, using plain language, he conveys his feelings of isolation, loneliness and helplessness. Being depressed watching the autumn scenery during the evening rain, he longingly thinks of her. His inability to answer her question, and the images of the evening rain along with the autumn pools may suggest that for them time passes terribly slowly. Their separation seems to drive him to despair. Therefore, he seeks solace in giving free rein to fantasy, imagining the two of them standing together by the window and trimming the lamp-wicks while remembering that apparently never-ending rainy evening embraced by the solitude of the mountain. And so he perfectly rounds the poem off in a simple and romantic way. 
LAVRAČ

\section{Conclusion}

The present study is focused on the interpretation of classical Chinese poetry, in our case Tang poetry which embodies the apex of Chinese literary tradition. It examines two of its most recurrent themes, parting from a dear friend or a lover, and separation and longing between husband and wife. The discussed poems were written by the masters of Tang verse as Li Bai, Wang Wei, Bai Juyi, $\mathrm{Du} \mathrm{Mu}, \mathrm{Du} \mathrm{Fu}$ and Li Shangyin who emphasized these two traditional themes by employing rich imagery. By their seemingly spontaneous yet actually thoughtful selection, they elevated each poem to a symbolic level. The images of the discussed poems function on both levels, as a description of scenery, and as symbols of a variety of feelings. The nature images as water or river, tumbleweed, drifting clouds, the setting sun, willows, grass, spring winds or spring breeze, moon or moonlight and evening rain, they are all associated with feelings at parting and separation. A significant image, playing an important role in this kind of situations, is also wine or a cup of wine symbolizing comfort and relief from care, fear or change, helping to cheer up the mood and alleviate the pain of suffering.

In most of the poems presented and investigated in The Theme of Parting section, the reason for parting from a friend is not clearly stated. However, in the last two farewell poems by Wang Wei this reason is more or less obvious. In the first one, the two friends are saying goodbye to each other due to the disappointment with the official career of the poet's friend and his final withdrawal to the mountains. In the second, Wang's friend has very likely to return to his official duties at the court in the capital after having visited the poet in his mountain retreat.

The last poem in this section was written by $\mathrm{Du} \mathrm{Mu}$, and,wrapped in the emotional turmoil of an imminent separation, it is a beautiful example of parting from a sweetheart.

The universal truth says, those who meet will part eventually. Yet the moments of experiencing the pain and sorrow of parting are also the moments that count in life, that can help to enrich its quality. A peaceful acceptance of whatever life has in stock for us, and let matters take their course, this is a world view eloquently embodied in this kind of poems.

The topic of separation and longing between husband and wife dominates all three poems introduced and discussed in the section The Theme of Separation and Longing yet each poem differs, for the unique authors have created distinctive masterpieces. While the poem by $\mathrm{Li}$ Bai is a picture of a common separation between husband and wife, the poem by $\mathrm{Du} F u$ and the one by Li Shangyin are rather subjective portrayals of a painful personal 
On Parting, Separation and Longing in the Chinese Poetic Tradition

experience. Anyway, they all express one's heart's longing for a beloved one who is far away from home. Despite the couple's gloomy situation, the hope in their eventual reunion is clearly expressed. In this way, it diminishes the suffering on both sides.

\author{
Maja Lavrač \\ maja.lavrac@guest.arnes.si \\ Filozofska fakulteta \\ Univerza v Ljubljani \\ Aškerčeva 2 \\ 1000 Ljubljana \\ SLOVENIJA
}

\title{
Bibliography
}

Chang, E. C. 2007. How to Read a Chinese Poem. A Bilingual Anthology of Tang Poetry. North Charleston,South Carolina: BookSurge Publishing.

Cheng, F. 1982. Chinese Poetic Writing. With an Anthology of Tang Poetry. Bloomington: Indiana University Press.

Barnstone, T., Barnstone, W., Xu, H. 1989. Laughing Lost in the Mountains. Selected Poems of Wang Wei. Beijing: Chinese Literature Press.

Deng, Shaoji 邓绍基, Shi, Tieliang 史铁良. 1992. Tangshi sanbaishou唐诗三百首. (Three Hundred Tang Poems). Dalian: Dalian chubanshe.

Feinerman, J. V. 1979. The Poetry of Wang Wei. [PhD diss.] New Haven: Yale University.

Frankel, H. H. 1976. The Flowering Plum and the Palace Lady. Interpretations of Chinese Poetry. New Haven and London: Yale University Press.

Hawkes, D. 1990. A Little Primer of Tu Fu. Hong Kong: The Chinese University of Hong Kong.

Herdan, I., trans. 1981. 300 Tang Poems. Taipei: Far East Book Co.

Johnson, S. M., trans. 2000. Fifty Tang Poems. San Francisco: Pocketscholar Press.

Lavrač, M. 1999. Onkraj belih oblakov. Daoistična in budistična simbolika v poeziji kitajskega pesnika Wang Weija. Maribor: ZaložbaObzorja.

Lavrač, M. 2000. Tradicionalna kitajska ljubezenska poezija. - Azijske in afriške študije, št. 2, let. IV, 16-25.

Lavrač, M. 2001. Li Bai and the Power of Expressiveness. - Asian and African Studies, Vol. 1-2, Year V,148-157.

Owen, S. 1981. The Great Age of Chinese Poetry. The High Tang. New Haven and London: Yale University Press.

Owen, S., ed. and trans. 1996. An Anthology of Chinese Literature. Beginnings to 1911. New York, London: W. W. Norton \& Company. 
LAVRAČ

Shi, Chunnian石椿年, Meng, Guangxue孟广学. 1973. Tangshi sanbaishou jinyi 唐诗 三百首今译(Three Hundred Tang Poems. New Translation). Tianjin: Tianjin guji chubanshe.

Wagner, M. L. 1975. The Art of Wang Wei's Poetry. PhD diss., Berkeley: University of California.

Watson, B. 1971. Chinese Lyricism. Shi Poetry from the Second to the Twelfth Century. New York: Columbia University Press.

Whincup, G. 1987. The Heart of Chinese Poetry. New York: Doubleday.

Xu Yuanzhong, Bei-Yei Loh, and Juntao Wu., eds. 1991. 300 Tang Poems. A New Translation. Hong Kong: The Commercial Press.

Yip, W. 1976. Chinese Poetry. Major Modes and Genres. Berkeley, Los Angeles, London: University of California Press.

Yu, P. 1980. The Poetry of Wang Wei. New Translations and Commentary. Bloomington: Indiana University Press.

\section{Internet References}

Bai, Juyi. Grass (in Chinese). - http://ts300.5156edu.com/html/162.html (03.01.2015).

Du, Fu. Moonlit Night (in Chinese). - http://ts300.5156edu.com/scall/z88s31c8285. html (03.01.2015).

$\mathrm{Du}, \mathrm{Mu}$. Given in Farewell (in Chinese). - http://ts300.5156edu.com/scall/ z31s30c8863.html (03.01.2015).

Li, Bai. Seeing Off a Friend (in Chinese). - http://ts300.5156edu.com/html/112.html (03.01.2015).

Li, Bai. Seeing Meng Haoran Off to Guangling (in Chinese). - http://ts300.5156edu. com/scall/z29s25c14604.html (03.01.2015).

Li, Bai. Spring Longing (in Chinese). - http://ts300.5156edu.com/scall/z68s47c13746. html (03.01.2015).

Li, Shangyin. For Someone In the North On a Rainy Night (in Chinese). -http:// ts300.5156edu.com/scall/z96s66c17429.html (03.01.2015).

Wang, Wei. Song of Wei City (in Chinese). - http://ts300.5156edu.com/scall/ z45s37c31016.html (03.01.2015).

Wang, Wei. Farewell (in Chinese, $1^{\text {st }}$ poem). - http://ts300.5156edu.com/scall/ z45s37c31016.html (03.01.2015).

Wang, Wei. Farewell (in Chinese, $2^{\text {nd }}$ poem). - http://ts300.5156edu.com/scall/ z52s73c30937.html (03.01.2015). 